\title{
PECULIARITIES OF THE FISCAL POLICY OF THE COUNTRY AGAINST THE BACKGROUND OF ACQUISITION AND ENFORCEMENT OF THE TITLE TO LAND IN UKRAINE
}

\author{
Yevheniia Duliba ${ }^{1}$ \\ Oleh Ilkiv ${ }^{2}$
}

DOI: https://doi.org/10.30525/978-9934-588-15-0-80

\begin{abstract}
The purpose of this research is to investigate the main features of forming and implementing fiscal policy of the state upon conditions of acquisition and exercise of title to land in Ukraine, management of land market, and withdrawal of moratorium on sale and purchase of lands of agricultural designation. The basis of this research is the state fiscal policy during introduction of the land market in Ukraine. At the heart of the research methodology is a dialectical method of scientific perception and system analysis of social phenomena that has given an opportunity to investigate the current state of forming and implementing fiscal policy in the course of land market administration in Ukraine. Combination of historical legal and rather-legal methods has provided an opportunity to discover historical, political, economic, legal, and social factors that have influenced and influence the forming, development, and realization of fiscal policy and organization of the land market in Ukraine. Results. The investigation has shown that the introduction of land market requires new fiscal policy with a fair distribution of profits and taxes. The specifity of operation of business entities in agricultural sector requires an adequate representation of tax treatment of agricultural enterprises in the tax law. The enjoyment of rights to the land has to be considered as fulfillment of rules of legal provisions of the land law concerning ownership and use of the land plots in practical activities of its subjects. Practical implications. The analysis of current issues associated with forming and development of fiscal policy upon conditions of acqui-
\end{abstract}

\footnotetext{
${ }^{1}$ Doctor of Law Sciences, Associate Professor,

Private Institution of Higher Education "International University of Economics and Humanities named after Academician Stepan Demianchuk", Ukraine

${ }^{2}$ Candidate of Law Sciences, Associate Professor,

Private Institution of Higher Education "International University of Economics and Humanities named after Academician Stepan Demianchuk", Ukraine
}

(C) Yevheniia Duliba, Oleh Ilkiv 
sition of title to land in Ukraine gives the possibility to determine a vector of development of economy of Ukraine and vector of development of the current legislation of Ukraine. Value/Originality. The performed investigation has provided a possibility to confirm the obtained results: opening of the land market in Ukraine will accelerate the development of economy that will provide an opportunity to increase budgets by means of rental payments from rights to permanent use and leasehold of city business and farmers. Improvement of fiscal policy in the course of land market administration in Ukraine should create conditions for development and support of economy of Ukraine, create fiscal conditions for legitimization of incomes and ensure reduction of events of evasion of the taxes payment, increase innovation and investment activities, and ensure stability of financial sector of economy. It is the fiscal policy that can ensure stability and strength of national economy, achievement of greatest possible welfare of the community through creation of proper conditions of socio-economic system.

\section{Introduction}

One of the main directions of the national policy of Ukraine is to ensure integration of the state into European political, economic, and legal space aimed at acquisition of membership in European Union [1]. Such a complicated socio-economic process of promotion of closer cooperation causes the increased overall dependence of Ukraine on other countries-members of European Union, and first of all in economic domain.

Now it has become quite obvious that Ukraine is a state with free market economy, however, further extension of its participation in global economic integration and strengthening of its position on global market require determination of specific legal instruments of promotion in global economic space, determination of directions of competitive recovery of national economy, and development of effective fiscal policy [2, p. 146].

Integration of Ukraine into global economic space is impossible without development of basic strategic directions of such integration, without implementation of reforms that could improve the reputation of Ukraine on international stage. The nagging problem of lack of or absence of funds in the state budget leads to the necessity for search for new sources of solving this problem by using international experience of economic crisis resolution and by provision of economic security of the state. 
It has become very important to implement a land reform, to establish a land market, and to call off a moratorium on sale and purchase of agricultural land in order to provide stable development and to form effective fiscal policy.

During many years the issue of necessity for cancelling the moratorium on sale and purchase of agricultural land has been topical and one of the most controversial. The supporters of moratorium withdrawal insist on the fact that the owners of farmland should have a right to dispose land plots belonging to them highlighting that moratorium leads to violation of the rights of the owners and to the existence of a shadow land market. At the same time, the opponents of free land sale and purchase point out the fact that the withdrawal of moratorium may result in deprivation of a great number of citizens of Ukraine of rights to land and in concentration of significant amount of land resources in hands of some great landowners, which could be found to be foreign producers.

Today the moratorium on sale and purchase of agricultural land has a significant negative effect on numerous areas of social and economic life in Ukraine and interferes its economic growth.

\section{Land and title to land in Ukraine}

Land is a natural object that is protected as the most important part of nature; it is a natural resource that is used as means of production in agriculture, forestry; it is a basis of carrying out business and other kinds of activity on the territory of Ukraine and at the same time it is used as an immovable property, item of property and other rights to land [3, p. 331-332].

In Ukraine the land plots are objects of land relations even before assignment of specific land plots and determination of title to them. In response, the land plots are independent objects of land relations [4, p. 15].

As a natural object and resource, the land is an integral immovable veneer of crust located above subsoil and territorially limited by the boundaries of Ukraine; it is a basis of landscape and spatial basis for well-balanced displacement of population and people's activity.

In domestic law doctrine the category "land plot" has different meanings. The land plot can be considered as an object of civil transactions 1 and as a primary item of national wealth2. In literature the land plot is suggested to be interpreted also as an object of legal construction and technical expertise [5, p. 17; 6, p. 10]. 
In general terms, land plot is a part of ground surface (in particular, top soil), boundaries of which are described and certified in accordance with established procedure.

In the doctrine of private law, land plot is defined as a part of ground surface located over subsoil that is immovable in its location, particularly determined in specific area due to its dimensions, boundaries, designated purpose, which are established by law, administrative regulation or agreement with obligations and rights to it of natural persons and legal entities [7, p. 100-105].

Traditionally in civil jurisprudence the land and everything that is closely associated with it (plants, buildings) are referred to immovable things, and other items belong to movable ones [8, p. 118].

In modern literature it is suggested to consider the term "immovables" to be a combined category aimed only at reflection of property-related nature of specific items. In particular, it is suggested to consider a land plot to be a kind of items of immovable property (land real estate) that is a part of ground surface with established boundaries and specific location, and with specific rights to it. The use of such an approach may result in transformation of land, buildings, facilities, etc. into independent objects of real estate, into the only one real estate item with indications of complex units.

It is reasonable to consider the land plot to be an integral immovable item consisting of inseparable accessions (buildings, facilities, plants).

Conditions and procedure of forming the land plot as an item of civil rights are defined by provisions of the Article 79-1 of the Land Code of Ukraine.

Land plot forming involves determination of the land plot as an object of civil rights. Land plot forming includes definition of its area, boundaries and entering data related to it to the State Land Cadastre (P. 1 p. 79-1 of the Land Code).

Land plot forming is carried out:

- by allocation of land plots from the land of state and communal ownership;

- by separation or assembly of previously formed land plots;

- by establishing boundaries of land plots of state or communal ownership according to the land survey projects associated with improvement of the territory of residential areas, land survey projects associated with improvement of the territory for city-planning demands, land survey projects associated with privatization of land of state and public utility agricultural enterprises, institutes, and organizations; 
- by inventory of land of state or communal ownership in cases prescribed by the law;

- according to the land survey projects associated with land plots (land shares) planning.

The land plot can become an object of civil rights exclusively from the moment of its forming (except cases of its sublease, easement over parts of the land plot) and state registration of title to this land plot.

State registration of property rights to land plots is carried out after state registration of the land plots in the State Land Cadastre.

State registration of subleasehold rights, easement related to any part of the land plot is to be carried out after entering data associated with this part into the State Land Cadastre.

Boundaries of adjacent land plots being subjects to private ownership may be changed by their owners without forming new land plots according to technical documentation of land use on establishment (renewal) of the site boundaries of land plots (Parts 2-12 Art. 79-1 of the Land Code).

The importance and complicity of the land plot as an object of rights are that being a living space the land plot is used for arrangement of quite different prizes of life, and its correlation with these prizes of life gives rise to the question of what exactly constitutes the land plot as an item except only the ground surface, what its correlation with movable things situated on the land plot is.

Although the law of Ukraine proclaims that the principle of land relations is a unity of legal fate of the land plot and of building (facility) located on it, but in fact it refers not to the sale of land plot, but to the sale of the building together with the land plot.

Land plots and buildings are considered to be independent items that exist independently of each other and may have different legal regimes as kinds of immovable property physically and legally related to each other [9, p. 28-29; 10, p. 34].

Title to land plot also refers to perennial plantings, which are on this land plot. In case of transfer of title to land plot, the title to perennial plantings on this land plot is also transferred to the owner.

According to the provisions of the Part 2 Art. 22, Art. 19 of the Land Code, perennial plantings are a kind of agricultural land belonging to lands of agricultural designation. 
According to the P. 2 Art. 79 of the Land Code, the title to land plot also refers to the ground surface (topsoil) within boundaries of the land plot, and also to water bodies, forests and perennial plantings located on it.

The same regulation concerning extension of title to land and to perennial plantings is specified by provisions of the Civil Code.

According to the P. 3 Art. 373 of the Civil Code, the title to land extends to surface soil (topsoil) within boundaries of this land plot, to water objects, forests, perennial plantings, which are located on it, and also to the space both above and under the surface of the land plot, with height and depth, which are required for construction of accommodation, industrial and other buildings and facilities.

Provisions of law of Ukraine concerning legal regime of subsoil and boundaries of enjoyment of right of ownership to land in space are indicative of reasonability of delimiting the land plots from the subsoil as objects of civil rights.

Civil and land law determine the boundaries of enjoyment of legal right of ownership to land in space (to the height and to the depth), extending field of such property right to topsoil (ground surface) within boundaries of the land plot, to water objects, forests, perennial plantings, which are located on it, and also to the space both above and under the surface of the land plot, with height and depth, which are required for construction of accommodation, industrial and other buildings and facilities (P. 3 Art. 373 of the Civil Code of Ukraine, P. 1 Art. 79 of the Land Code of Ukraine). Prescribed by the Civil and Land Codes of Ukraine boundaries of enjoyment of the right of ownership to height and depth of the land plot extend to all subjects to title to the land plot.

In contrast to title to land that can be both in possession (use) and at the property of natural persons and legal entities, the subsoil belongs solely to the Ukrainian people and can be transferred for use for individual persons only for temporary use.

\section{Peculiar features of land value taxation in Ukraine}

From the very beginning of Ukraine's independence the taxation of subjects of entrepreneurial activity engaged in agrarian activity has been distinguished by availability of specific tax treatment and possibility to choose simplified taxation system - flat agricultural tax; that has successfully pro- 
moted agrarian business. It has not restricted savings and has been aimed at quickest possible enrichment of subjects of entrepreneurial activity.

After adoption of the Law of Ukraine On Making Amendments in the Tax Code of Ukraine and in Several Regulatory Acts of Ukraine concerning Tax Reform dd. 28.12.2014 the flat agricultural tax was joined (almost without amendments) with a single tax within the context of reduction of tax number. It has become a single tax of the $4^{\text {th }}$ group [11].

Besides, business entities, which had performed their activities in agrarian sector (in particular, in agriculture, forestry, and fishery), had been subjects to general tax system and had fulfilled the prescribed criteria, were given the possibility to use special VAT regime till 2015. Its specific feature was that a tax amount, which was charged on cost of supplied own-produced agricultural goods/services, was not paid to the budget, but remained at disposal of goods producer for the purpose of tax reimbursement for purchased goods/services, which formed a tax credit, and in case of availability of a balance it could be used for production purposes. However, the special VAT regime has been also cancelled, reasoning that today the agrarian sector produces rather little tax revenues, but at the same time the expenses for different kinds of agricultural assistance show a great percent and the larger part of it is paid for VAT recovery. Furthermore, VAT recovery costs go to large agricultural goods producers, which have all possibilities to pay VAT.

Today the agricultural goods producers are subjects to general tax system or may choose simplified taxation system in the form of single tax of the $4^{\text {th }}$ group.

The agricultural goods producers that choose the general tax system are obliged to pay the following taxes: income tax, value added tax, tax on property (land tax), and rental payments for special water usage. Now the land tax is a part of land fees and is included into the tax on property. This tax is essential for agricultural business as none of the sectors of agriculture can develop without use of agricultural land (agriculturally or nonagriculturally used areas) [12].

Therefore, at first regimes that promoted the development of agricultural sector and further special tax regimes were not supported with new reforms, and the moratorium that was imposed on sale and purchase of land facilitated the development of the shadow market, raidership, corruption, and evasion of payment of taxes and other fees. 
Today agricultural lands make $70 \%$ from the total area of land of Ukraine [13]. However, because of the currently valid moratorium it is forbidden to sell, donate, pledge or assign in any other way $96 \%$ of all farmlands being privately owned, and also all state and communal lands. The existing prohibition on agricultural land trade promotes the development of rental market.

According to par. 287.1 Art. 287 of the Tax Code of Ukraine, land owners and land users pay land fees from the date of emergence of title to land or land leasehold. Data from the State Land Cadastre is a basis for calculation of the land tax. In case of termination of title to land or land leasehold the land fee is to be paid for actual period of the land being in ownership or in use during the current year.

According to Art. 125 of the Land Code of Ukraine dd. October 25, 2001 No. 2768-III as amended and supplemented (hereinafter - LCU), the title to the land plot and also right of perpetual use and land leasehold emerge from the moment of state registration of such rights.

The Article 126 of the LCU defines that right to ownership and right of use of the land plot should be registered according to the Law of Ukraine dd. July 01, 2004 No. 1952-IV On State Registration of Real Rights to Immovable Property and Their Encumbrances, as amended and supplemented (hereinafter - Law No. 1952).

State registration of real rights to immovable property and their encumbrances is an official approval and confirmation by the state of facts of acquisition, variation or termination of real rights to immovable property, encumbrances of such rights by entering correspondent data into the State Register of Real Rights to Immovable Property (par. 1 of the Part I of Art. 2 of the Law No. 1952).

At the same time paragraph two of item 286.5 of Art. 286 of the Tax Code of Ukraine states that in case of transfer of title to land from one owner - legal entity or natural person - to another during calendar year, the tax should be paid by the previous owner for the period from January 01 of the current year till the beginning of the month, when the title to aforesaid land plot terminates, and the new owner should pay tax beginning from the month, when he gains the title. Besides, if the transfer takes place later than July 01 of the current year, then regulatory authority sends (serves) to the previous owner a new tax assessment note - the decision, the previous tax assessment note - the decision is considered to be cancelled [14]. 
Having no land in property the subjects of entrepreneurial activity have begun to use land by lease. Large subjects of entrepreneurial activity have gradually concentrated hundreds of small land plots under their control precisely due to lease agreements, and public authorities have leased stateowned lands through public e-auctions. Thus, the subjects of entrepreneurial activity have found a legal way to avoid moratorium and today it is obvious that delaying new stage of tax reform will accumulate and enhance "oligarchical pressure" on the land reform. "Latifundium trend" on the land market is based not only on monopoly of big business in lease relations, but also on financial superpowers of its purchase. In Ukraine the existing tax system works for big business based on agroholdings.

It is worth mentioning that today the land fee, which is paid in form of land tax and land rent for plots of state and communal property, is the second largest revenue source for local budgets. According to experts' opinions, because of ineffective land management, the local budgets annually receive approximately 1.0-1.5 billion UAH less. This, in its turn, significantly weakens material and financial capabilities of local governments and restrains the development of rural areas.

\section{Ukrainian land and foreign investments}

Ukrainian land has been always of great interest for foreign investors as means of production and object for investments. For a rather long period, the tendency of raise of such interest has not changed and in the immediate future there will be definitely no reasons for this interest to become weaker (certainly, except force majeure risks). Taking into consideration the central importance of land for any state as strategic asset, the regulation of property relations and land use takes a separate place, perhaps, in all developed legal systems. In Ukraine when dealing with land, one should take into consideration the specific attitude of Ukrainians towards their land.

In this respect our country has rather specific position - it belongs to the minority of developed countries, where there is a moratorium on sale of land by their owners. This moratorium is limited to land of agricultural designation, which, without exaggerations, in Ukraine is the main wealth. Nevertheless, the agricultural land market has developed, but due to the force of the aforesaid moratorium it is imperfect in many aspects and its rules are not always transparent and understandable for foreigners. 
When making investments, foreign citizens and legal entities can also be subjects to land relations, acquiring and exercising rights to land plots. However, in Ukraine the acquisition and enjoyment of the rights to land by nonresidents take place with certain restrictions.

In accordance with the applicable legislation of Ukraine, the possibilities and procedure of acquisition of ownership or receiving for use of land plots should be determined separately. Thus, according to the current edition of the Land Code of Ukraine (LCU), the foreign legal entities may acquire the title to land plots of nonagricultural designation:

a) within boundaries of inhabited localities - in case of purchase of items of immovable property and for construction of objects associated with conducting business in Ukraine;

b) outside the boundaries of inhabited localities - in case of purchase of items of immovable property.

Joint ventures established in partnership with foreign legal entities or natural persons may acquire the title to land plots of nonagricultural designation in cases defined in LCU and according to the procedure prescribed for foreign legal entities. Lands of agricultural designation inherited by foreign legal entities are subjects to alienation during the year.

An application has to be submitted together with a document that certifies the title to immovable property (buildings and facilities) situated on the land plot and a copy of certificate of registration of permanent establishment with the right to conduct economic activities on the territory of Ukraine made by foreign legal entity. Unlike the right of ownership, there are no other restrictions for lease or other kinds of use of lands in Ukraine for foreign legal entities, however, there are still some requirements to participation in land tendering in order to acquire leasehold of land being in state or communal ownership, this has to be taken into consideration when preparing documents required for participation in such tendering. Except the legislation itself, it is reasonable for foreign business to concern itself with practice of its interpretation and application. For instance, when clarifying the tax law, the State Fiscal Service points out the necessity of registering the nonresident having in ownership the immovable property on the territory of Ukraine in one of the following ways:

- permanent establishment of nonresident;

- separate subdivision of nonresident (representative establishment of nonresident); 
- property administrator;

- legal entity with foreign investments.

Thus, the acquisition of rights to lands by foreign legal entities is directly associated with the purchase or creation of objects of immovable property, and in certain cases - with registration of permanent establishment. At the same time the legislation clearly states that foreign companies may acquire the right of ownership of lands of nonagricultural designation. That means that if the foreign company has an intention to register the real right to land directly for itself, including also leasehold, from the perspective of fiscal authorities it should set up here one of the suggested kinds of permanent establishments.

This approach is considered to be reasonable from the perspective of fiscal authorities with respect to the necessity of paying taxes imposed for owners and users of land plots. Today there are cases of real property holding by companies-nonresidents without registration of the permanent establishment for taxation purpose, but in fairness it is worth mentioning that when carrying out title registration registrars do not ask for documents of registration of permanent establishment (at least for the time being).

The aforesaid regulations give a possibility to conclude that in case of "sudden" withdrawal of moratorium on sale of agricultural lands the legislation of Ukraine includes the above mentioned "protectors" from transfer of such lands into ownership of foreign companies. Taking into account a recent constitutional petition to Constitutional Court of Ukraine concerning constitutionality of the said moratorium initiated by deputies, these "protectors" may become fully operative rules.

\section{New fiscal policy with regard to taxation of lands of agricultural designation}

In the process of transformational changes of domestic agriculture-based economy the most of agricultural enterprises have faced a critical situation due to imperfection of the system of business and financial credit mechanisms of economic management. Under conditions of activation of market environment, strategic development of agrarian sector of economy becomes visible not only through direct state financial support of agricultural producers, but also through special terms of taxation, as effective agrarian business operations are possible only upon condition of stability and predictability of the tax law providing an opportunity of optimal tax burden. 
The Land Code of Ukraine defines the title to land as a right to possess, to use, and to manage land plots. For this reason the prohibition on the sale of land plots of agricultural designation is a limitation of title to land. The absence of the possibility of its sale makes it impossible to grant credits for agricultural producers secured on the land, and absence of funds makes the development of small agrarian producers, e.g. farm enterprises, impossible.

There are no doubts that the land law needs to be systematized and updated in order to eliminate contradiction and collisions. However, during 17 years of the validity of moratorium Ukraine has not even come close to the objectives set at the moment of this moratorium implementation. As of today, the legislation concerning the farmland market has not been adopted and only draft laws have been regularly introduced having both supporters and opponents.

The Special-Purpose Committee of Verkhovna Rada concerning issues of agricultural policy and land relations, Ministry of Agrarian Policy and Food, StateGeoCadastre are the main players in realization of legislative initiatives on land relations, which often have quite opposite view on legal regulation of land market, besides, even inside these institutions there is no coherence. And as a result, in October 2016 the moratorium on farmland sale was prolonged once again.

And in the meanwhile despite the moratorium, the land has been actively and continuously bought up, new and new "shadow schemes" for its purchase have been created, and definitely, that in no way facilitates the protection of rights of farmlands owners.

Moreover, the introduction of land market requires the development of new fiscal policy with a fair distribution of profits and taxes. The specifity of operation of business entities in agricultural sector requires an adequate representation of tax treatment of agricultural enterprises in the tax law.

The taxation of agricultural goods producers has to fulfill not only fiscal, but also regulatory functions, to be an instrument of state support and stimulation of production, to ensure competitiveness of national agriculture and implementation of innovations into production. New fiscal policy should have significant tax exemptions for those business entities that promote the development of villages and enrichment of rural population, including also providing ability for them to buy the land.

Fiscal policy of any state is an important instrument of management of the economy due to its ability to influence the stabilization of economic growth, 
avoidance of economic crises, overall production, increase or decrease of demand for goods and services, increase or reduction of prices on consumer market. Fiscal policy serves for provision of stability and strength of national economy, achievement of greatest possible welfare of the community through creation of proper conditions of socio-economic system.

Fiscal policy allows to form taxes, to spend funds from the state budget to regulate the level of business activity and to solve various social problems, that is it is aimed at regulation of incomes and expenses of the state $[15$, p. 62].

We assume that now it is necessary to improve the tax law, first of all, to ensure the stability of the tax law. The relative stability of the tax law is one of the conditions for tax system to operate successfully. It is relative due to the fact that objective need for implementation of tax reforms as such conflicts with inviolable stability. In this situation Western countries show a kind of compromise: tax rates, exemptions, various limits are subject to periodical (annually, once every three years) review, and rules of collection and administration can remain the same during many years [16, p. 161].

First of all, fiscal policy should be based on the principle of stability. In the Tax Code of Ukraine the principle of stability is defined as changes to any elements of taxes and levies that can be made not later than six months till the beginning of new budgeting period, in which new rules and rates of the Tax Code of Ukraine come into force [12]. Taxes and levies, their rates and also tax exemptions cannot be changed during a budget year. However, the changes made each year in the Tax Code of Ukraine demonstrate not only instability of the law, but also, in particularly, inefficiency of tax policy realization. Analysis of changes made in the Tax Code of Ukraine over recent years just confirms the complexity of the tax law and violation of principles of socio-economic justice and equality. As a result, taxpayers do not know what taxes will be implemented in the immediate future, state institutions do not know what amount of funds they will have available in the medium-term perspective, and citizens do not know for what purposes the budget funds will be provided and what services will be available for them. It is just the absence of an integral system of strategic planning that does not allow making provision for budget planning at the appropriate level and that leads to weakening of connections between budget programs and priorities of the development of the state [17]. Nowadays the global 
experience of many countries shows that in tax codes there are regulations, which determine that any tax changes require certain period for them to come into force.

It is worth mentioning that the state has to create favorable conditions for forming, operation, and development of economy and to ensure stability and competitive recovery of national economy [18, p. 388]. Strong economic transformations require considerable budget expenses [19, p. 164]. Improvement of fiscal policy should create conditions for development and support of economy of Ukraine, create fiscal conditions for legitimization of incomes and ensure reduction of events of evasion of the taxes payment, increase innovation and investment activities, and ensure stability of financial sector of economy.

When making further amendments into the Tax Code of Ukraine aimed at improvement of taxation of agricultural business, it is necessary to comply with certain requirements as accuracy in land taxation depends on many factors and first of all on what the conditions of land plot disposal are transfer into ownership, assignment for permanent use, or lend lease; what designated use of land plots is, as the destination determines categories of land plots; and on the availability of a normative estimated money value. Besides, it is necessary to take into consideration specific aspects of agricultural business operation (duration of production and considerable time breaks between the beginning of production and goods receipt), limited purchasing capacity, disparity of prices for products and means of their production, various dependence on natural and climatic conditions, profitability of agricultural sectors and other factors, and also to take into account interdependence of agricultural goods producers and other business entities of agricultural complex; it is necessary to prevent discrimination among agricultural goods producers. The taxation has to be based on land fee and even tax burden, considering the profitability of production, and when imposing taxes on small agricultural goods producers (family farms) tax exemptions and preferences and tax holidays for newly created small business entities should be implemented. New tax system has to promote living in rural areas, capitalization of farm assets development of self-management and business activity in rural regions.

Opening of the land market will accelerate the development of economy both in cities and in rural regions. For rural areas this will provide an 
opportunity to increase budgets by means of rental payments from rights of city business and farmers to permanent use and leasehold. At that, there would be a possibility to reduce fiscal burdens on business incomes and employment taxes; that can create the basis for competitive advantages and business incentive.

We believe that the moratorium on land alienation should be cancelled, but at the same time it cannot be done without thorough advance preparation. Conditions for cancellation should be carefully considered in order to prevent alienation of lands at prices lower than fair market values, possibility of uncontrolled redistribution of land market and legal uncertainty concerning issues of the use of common infrastructure facilities. The additional required condition is the completeness of filling out the land cadaster that is considered to be a guarantee of the rights of landowners, and also acknowledgment of the fact that the land plot is a complete item of immovable property.

\section{Conclusions}

The introduction of land market in Ukraine requires the development of new fiscal policy with a fair distribution of profits and taxes. The specifity of operation of business entities in agricultural sector requires an adequate representation of tax treatment of agricultural enterprises in the tax law.

Among all guarantees of protection of title to land the guarantees of title to land plot are important. This right is acquired and exercised by citizens, legal entities, and state in accordance with the law. The reason for the title to land is a jural fact, with which the creation of such right is associated according to the law. Jural facts, on basis of which the title to land accrues, include: a decision of authorities concerning transfer of land plot into private ownership of the citizen; civil contract; inheritance of the land plot, etc.

The opening of the land market in Ukraine may have both positive and negative results; however, this will depend on the state policy in our country. Certainly, one has to understand that opening of the land market is not only an instrument to increase budget, but also a matter of strategic security of Ukraine. Therefore, first of all, it is necessary to take a certain set of actions to protect state interests, including economic ones.

The opening of the land market in Ukraine will accelerate the development of economy that will provide an opportunity to increase budget by 
means of rental payments from rights of city business and farmers to permanent use and leasehold. Improvement of fiscal policy in the course of land market administration in Ukraine should create conditions for development and support of economy of Ukraine, create fiscal conditions for legitimization of incomes and ensure reduction of events of evasion of the taxes payment, increase innovation and investment activities, and ensure stability of financial sector of economy. It is the fiscal policy that can ensure stability and strength of national economy, achievement of greatest possible welfare of the community through creation of proper conditions of socio-economic system.

The enjoyment of rights to lands should be considered as fulfillment of rules of legal regulations of the land law concerning ownership and use of the land plots (objective right) in practical activities of its subjects (subjective right).

Procedure of enjoyment of title to land requires the performing of certain functions by executive authorities or local government authorities, or by other subjects with application of these regulations. On the other hand, the performing of certain functions is possible only upon condition of following the procedure of management activity prescribed by land procedural regulations. Significant complex of substantive land and legal regulations, which regulate social relations related to title to land, can be realized only by means of legally significant law-enforcement activity of executive authorities and local government authorities. The process of their activity is regulated by procedural rules of the land law and by other branches of legislation.

\section{References:}

1. On Principles of Domestic and Interior Policy: Law of Ukraine dd. 01.07.2010 No. 2411-VI. Retrieved from: http://zakon.rada.gov.ua/laws/show/2411-17 (in Ukrainian)

2. Duliba Ye., Ilkiv O. (2017). Aktualni problemy intehratsii Ukrainy u svitovyi ekonomichnyi prostir [Relevant Problems of Ukraine's Integration into Global Economy]. Baltic Journal of Economic Studies, vol. 3, no. 5, pp. 146-150. DOI: http://dx.doi.org/10.30525/2256-0742/2017-3-5-146-150

3. Spasybo-Fatieieva I.V. (2012). Kharkivska tsyvilistychna shkola pravo vlasnosti [Kharkiv School of Civil Law: Right to Property]. Kharkiv. (in Ukrainian)

4. Niekriestianov D.S. (2005). Civil and Legal Regulation of Circulation of Objects of Construction in Progress: dissertation abstract. Candidate of Legal Sciences.

5. Andreitsev V.I. (2004). Zemlia yak osnovne natsionalne bahatstvo orhanizatsiino-pravovi problemy rozvytku ahrarnoho i zemelnoho rynkiv $\mathrm{v}$ Ukraini [Land as a Primary Item of National Wealth: Issues of Legal Regime/ Organizational and Legal Problems of Development of Agrarian and Land Markets 
in Ukraine]. Kyiv: Institute of State and Law named after V.M. Koretskyi of the National Academy of Sciences of Ukraine.

6. Bielousenko M.V. (2004). Zkonomicheskaya zffektivnost' sobstvsnnosti: tsorsticheskiy aspekt [Economic Efficiency of the Ownership: Theoretical Aspect]. Industrial Economics, no. 3, p. 10.

7. Sydorenko N.N., Klymenko I.V., Kalarash N.V. (2005). Zemel'niy uchastok kak ob'yekt issledovaniya sudebno-tekhnicheskoy zkspertiz'i [Land Plot as an Object of Legal and Technical Expertise Investigation]. Materails of the VII Report Research-to-Practice Conference of Academic Staff and Students of the Crimean Institute of Law of the National University of Internal Affairs. P. 100-105.

8. Vaskovskyi Ye.V. (2003). Uchebnik grazhdanskogo prava [Book of Civil Law]. Moscow: Statut. (in Russian)

9. Germanov A.V. (2011). Zemel'nyy uchastok v sisteme veshchevykh prav. Moscow: Statut. (in Russian)

10. Maksimova Ye. (2004). Perekhod prav na zemel'nyy uchastok pri perekhode prava sobstvennosti na zdaniye, stroyeniye, sooruzheniye [Transfer of Title to Land at Transfer of Title to Building, Construction, Facility]. Ecological Law, no. 5, p. 34.

11. On Making Amendments in the Tax Code of Ukraine and in Several Regulatory Acts of Ukraine concerning Tax Reform: Law of Ukraine dd. 28.12.2014 No. 71-VIII. Retrieved from: https://zakon4.rada.gov.ua/laws/show/71-19 (in Ukrainian)

12. Tax Code of Ukraine: Law of Ukraine dd. 02.12.2010 No. 2755-VI. Retrieved from: http://zakon2.rada.gov.ua/laws/show/2755-17 (in Ukrainian)

13. Infohrafika: Struktura ukrainskykh zemel ta spivvidnoshennia kilkosti chornozemiv $\mathrm{v}$ ukraini ta inshykh ievropeiskykh krainakh Retrieved from: https://land.gov.ua/info/infohrafika-struktura-ukrainskykh-zemel-ta-spivvidnoshenniakilkosti-chornozemiv-v-ukraini-ta-inshykh-ievropeiskykh-krainakh (in Ukrainian)

14. Perekhid prava vlasnosti na zemelnu dilianku osoblyvosti opodatkuvannia. Retrieved from: https://uteka.ua/ua/publication/news-14-ezhednevnyj-buxgalterskijobzor-39-perexod-prava-sobstvennosti-na-zemelnyj-uchastok-osobennostinalogooblozheniya (in Ukrainian)

15. Duliba Ye.V. (2018). Fiskalna funktsiia derzhavy administratyvno-pravovyi aspekt [Fiscal Function of the State: Administrative Aspect]. Nizhyn: Nizhyn Mykola Gogol State University. (in Ukrainian)

16. Andrushchenko V.L., Varnalii Z.S., Prokopenko I.A., Tuchak T.V. (2012). Podatkovi systemy zarubizhnykh derzhav navchalnyi [Tax Systems of Foreign Countries]. Kyiv: Kondor. (in Ukrainian)

17. On Approval of Strategy of Reforming the System of Public Financial Management for 2017-2020: Order of the Cabinet of Ministers of Ukraine dd. February 08, 2017 No. 142-p. URL: http://zakon.rada.gov.ua/laws/show/142-2017-\%D1\%80 (in Ukrainian)

18. Bilotserkivets V.V., Zavhorodnia O.O., Lebedieva V.K. (2012). Mizhnarodna ekonomika [International Economy]. Kyiv: Learning Resource Center. (in Ukrainian)

19. Bilotserkivets V.V., Zavhorodnia O.O., Lebedieva V.K. (2012). Mizhnarodna ekonomika [International Economy]. Kyiv: Learning Resource Center. (in Ukrainian) 